\title{
Magnetic Mountain
}

Stalinism as a Civilization

STEPHEN KOTKIN

University of California Press

BERKELEY LOS ANGELES LONDON 
The publisher gratefully acknowledges the contribution provided by the General Endowment Fund of the Associates of the University of California Press.

\section{University of California Press \\ Berkeley and Los Angeles, California}

University of California Press, Ltd.

London, England

(C) 1995 by

The Regents of the University of California

First Paperback Printing 1997

Kotkin, Stephen.

Magnetic mountain : Stalinism as a civilization / Stephen Kotkin.

p. cm.

Includes bibliographical references (p. ) and index.

ISBN978-0-520-20823-0 (pbk.: alk. paper)

1. Magnitogorsk (Russia)-History. 2. Soviet Union-Politics and government. 3. Communism--Soviet Union--Case studies.

i. Title.

DK651.m159K675 1995

$947^{\prime} .87-\mathrm{dc20}$

94-11839

CIP

Printed in the United States of America

$10 \quad 0908$

1211 10 9

The paper used in this publication meets the minimum requirements of ANSI/NISO Z39.48-1992 (R 1997) (Permanence of Paper).

A version of chapter 2 was first published in William Rosenberg and Lewis Siegelbaum, eds., Social Dimensions of Soviet Industrialization (Bloomington: Indiana University Press, 1993); of chapter 4 in William Brumfield and Blair Ruble, eds., Russian Housing in the Modern Age: Design and Social History (New York: Cambridge University Press, 1993); and of chapter 5 in Lewis Siegelbaum and Ronald Suny, eds., Making Workers Soviet: Power, Class, and Identities (Ithaca: Cornell University Press, 1994). 
Magnetic Mountain 


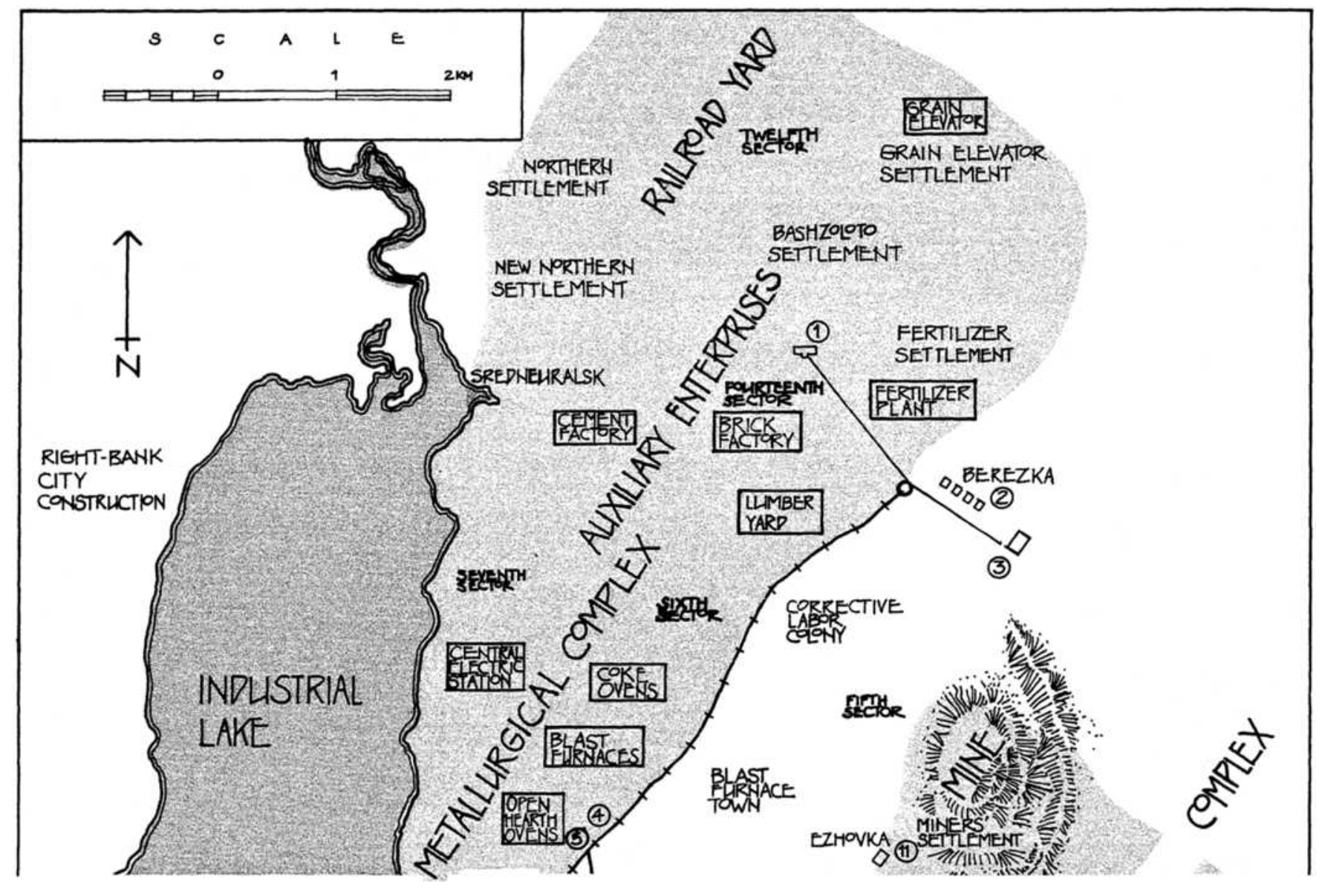




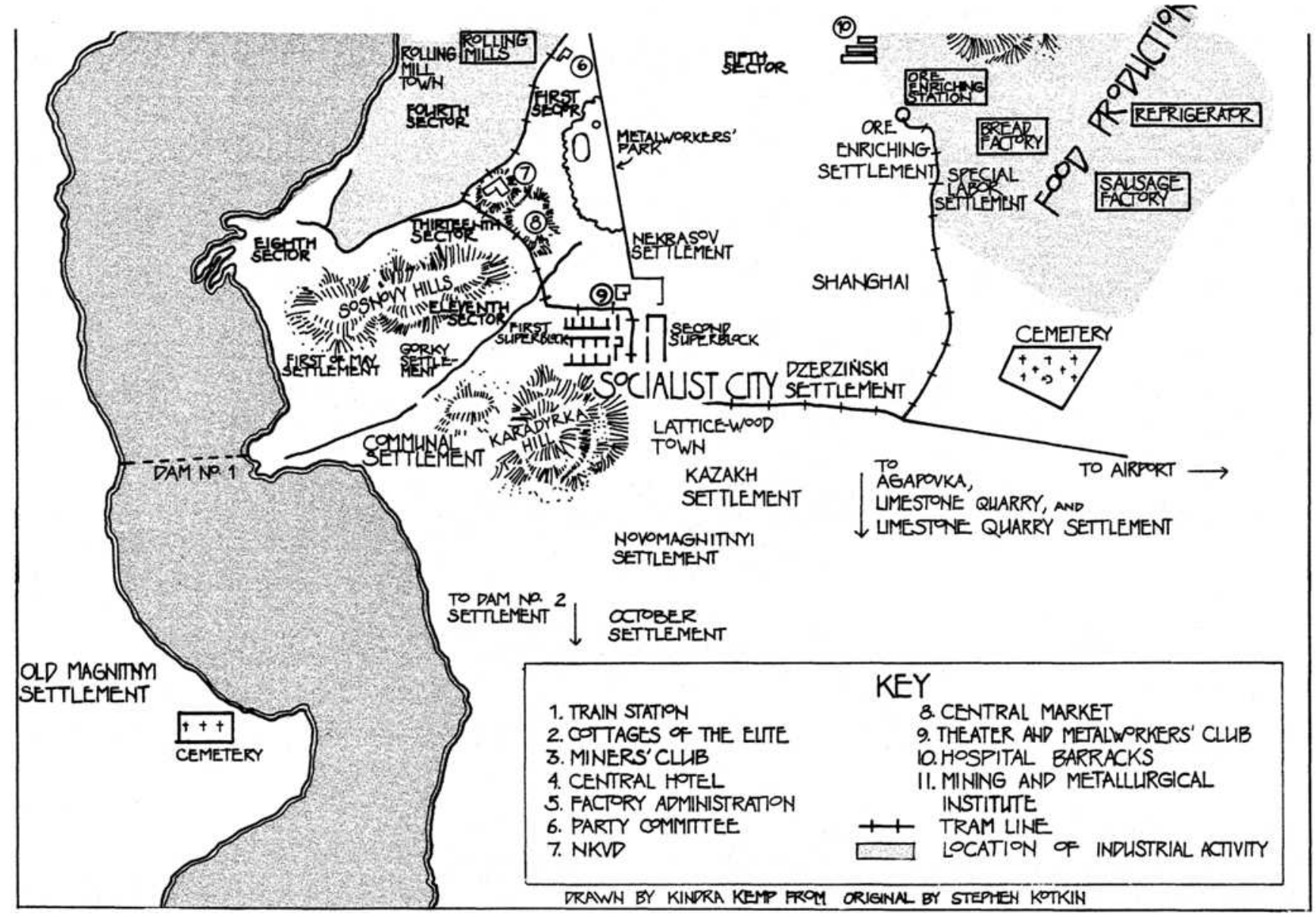

Magnitogorsk, 1939 
This page intentionally left blank 
To M. F. 
This page intentionally left blank 
I propose a toast to simple, ordinary, modest people, to the "little cogs" who keep our great state machine in motion. . . No one writes about them, they have no high titles and few offices, but they are the people who maintain us. . . I drink to the health of these people.

Joseph Stalin 
This page intentionally left blank 